\title{
Did public health travel advice reach EURO 2012 football fans? A social network survey
}

J Janiec (jjaniec@pzh.gov.pl)ㄹ, A Zielicka-Hardy',2, A Polkowska²,3, J Rogalska',4, M Sadkowska-Todys ${ }^{1}$

1. Department of Epidemiology, National Institute of Public Health- National Institute of Hygiene, Warsaw, Poland

2. European Programme for Intervention Epidemiology Training (EPIET), Surveillance and Response Support Unit project on mass gatherings support, European Centre for Disease Prevention and Control (ECDC), Stockholm, Sweden

3. National Institute for Health and Welfare (THL), Helsinki, Finland

4. Health Protection Surveillance Centre, Dublin, Ireland

Citation style for this article:

Janiec J, Zielicka-Hardy A, Polkowska A, Rogalska J, Sadkowska-Todys M. Did public health travel advice reach EURO 2012 football fans? A social network survey. Euro Surveill. 2012;17(31):pii=20238. Available online: http://www.eurosurveillance.org/ViewArticle.aspx?Articleld=20238

We posted a survey on the Union of European Football Associations (UEFA)'s EURO 2012 Facebook profile to evaluate whether public health travel advice, specifically on the importance of measles vaccination, reached fans attending EURO 2012. Responses suggested that these messages were missed by $77 \%$ of fans. Social networks could serve as innovative platforms to conduct surveys, enabling rapid access to target populations at low cost and could be of use during upcoming mass gatherings such as the Olympics.

During the European football tournament (EURO 2012) held between 8 June and 1 July 2012, approximately 1 million people travelled to Poland and Ukraine. Mass gatherings of this scale provide an environment for potential rapid spread of infectious diseases $[1,2]$. The current prevalence of measles in Europe and the ongoing measles outbreak in Ukraine [3] lead to prioritisation of this disease as a potential threat to visitors of the event. Pre-travel health advice issued by international organisations such as the World Health Organization (WHO) and the European Centre for Disease Prevention and Control (ECDC) as well as national health authorities recommended measles vaccination to all Euro 2012 visitors [4]. Public health messages were released via a number of different platforms including leaflets, official public health websites, other websites and the media.

Although often a lot of effort is invested in the preparation of travel health advice during mass gatherings, little published information is available to date on the degree to which messages reach the general public during such events. The aim of this study was to determine whether public health messages reached persons travelling to EURO 2012.

\section{Methods}

We conducted a cross-sectional study among EURO 2012 fans. We set up an anonymous, self-administered, internet-based survey on the Union of European Football Associations (UEFA)'s EURO 2012 Facebook profile [5]. The questionnaire was designed using Survey Monkey (www.surveymonkey.com/). It consisted of 10 questions on personal characteristics (country of residence, sex, age), hosting countries visited during the tournament, and sources of travel health advice received, if any. We divided travel health advice into two categories: actively seeking information (Did you actively seek any travel health advice before coming to Poland and/ or Ukraine for EURO 2012? And if yes where did you find it?) versus passively receiving information. i.e. hearing/receiving information by chance (Aside from information you found yourself, did you see or hear any health advice related to EURO 2012? and Where did you see or hear this health advice?). The choice of possible answers was different for these two categories, but some answers were possible in both, e.g. public health websites, which may have been browsed by people seeking information related to EURO 2012 or by people seeking unrelated information who may have seen the travel health advice only by chance.

We predominantly used closed-ended questions. Some questions were added to detect errors and inconsistencies, e.g. respondents were asked twice, in different parts of the questionnaire, whether they travelled to any of the hosting countries. Our sampling frame consisted of approximately 1 million people who travelled to matches in Poland or Ukraine. We attempted to reach these fans through the UEFA's Facebook profile (http://www.facebook.com/uefaeuro2012), and also through the Google+ UEFA.com profile (https://plus. google.com/s/uefa\%2osurvey; https://plus.google. com/105904468979374711712/posts), the WHO immunization week blog (http://eiw.euro.who.int/) and Facebook page (apps.facebook.com/afbcaad/), and EU_Health twitter (https://twitter.com/EU_Health). The survey was posted three days after the final match and kept active for a period of two weeks. Analysis was mainly restricted to respondents who visited at least one of the hosting countries during EURO 2012. The analysis also included people residing in Poland or Ukraine. In order to determine differences between fan 
groups, we used uncorrected chi-square and Fisher's exact tests.

\section{Results}

We received responses from 313 people from 67 countries. Nearly all questions were answered by a different number of respondents. The question with the lowest response rate was answered by 256 people (82\%). Comparisons between sexes and the category of country people travelled from were restricted to the 111 individuals who actually attended EURO 2012 in either or both of the hosting countries (Table). These individuals had a median age of 27.4 years (range: $9-57$ years), and $79 \%$ were male. Of this group, 111 answered the question about actively seeking information, 27 reported they did seek information, and 84 answered that they did not. The question about receiving health information passively was answered by 107 individuals, and 32 answered that they did, 57 answered that they did not, and 18 that they did not remember. There were no significant differences in the responses on travel health advice with regard to the respondents' sex or the country they travelled from, including countries outside Europe (Table). Based on the 304 who answered the question whether they travelled to Euro 2012 or not, respondents who did not attend the tournament were less likely to recall any form of travel health advice, compared with those who attended.

Among fans who actively sought travel health advice, General Practitioners/doctors were the most common source of information. For those who passively received information, the media was the most frequent channel of communication (Figures 1 and 2).

Information regarding the importance of measles vaccination had reached $23 \%$ of 108 respondents who attended the tournament and answered this question. There was no statistically significant difference between people from countries with rates of measles notification of over one per 100,000 population [3] compared with those below this threshold (Table).

\section{Discussion}

Among the respondents attending EURO 2012, 24\% recalled actively seeking any kind of travel health advice, and 30\% reported they received it passively. This can indicate either that it was not a priority for all fans or that advice was not appropriately disseminated. Despite the efforts made by public health organisations to raise awareness regarding measles vaccination and the continuous media coverage, both before and during EURO 2012, messages went unnoticed by a significant number of fans attending the tournament. It may be that people travelling to or within Europe have a false sense of security when it comes to health. To effectively disseminate health messages to the general public and capture their attention, new communication strategies need to be adjusted to today's society.

Our study showed that social networking sites, particularly Facebook, serve as innovative platforms for

TABLE

Comparison of information seeking behaviour among surveyed fans, European football tournament 2012

\begin{tabular}{|c|c|c|c|c|c|c|c|c|c|}
\hline \multirow[b]{2}{*}{ Comparison between: } & \multicolumn{3}{|c|}{$\begin{array}{c}\text { Did you actively search for travel } \\
\text { health information? }\end{array}$} & \multicolumn{3}{|c|}{$\begin{array}{c}\text { Did you passively receive travel } \\
\text { health information? (i.e by chance) }\end{array}$} & \multicolumn{3}{|c|}{$\begin{array}{l}\text { Did you receive information on the } \\
\text { importance of measles vaccination? }\end{array}$} \\
\hline & $\begin{array}{l}\text { Total } \\
\text { answers }\end{array}$ & $\begin{array}{l}\text { Answered } \\
\text { yes (\%) }\end{array}$ & $\mathrm{p}$ value & $\begin{array}{c}\text { Total } \\
\text { answers }\end{array}$ & $\begin{array}{l}\text { Answered } \\
\text { yes (\%) }\end{array}$ & $\mathrm{p}$ value & $\begin{array}{c}\text { Total } \\
\text { answers }\end{array}$ & $\begin{array}{l}\text { Answered } \\
\text { yes (\%) }\end{array}$ & $\mathrm{p}$ value \\
\hline Females & 24 & $2(8)$ & \multirow{2}{*}{$0.06^{\mathrm{a}}$} & 23 & $8(35)$ & \multirow{2}{*}{0.6} & 23 & $5(22)$ & \multirow{2}{*}{$0.9^{\mathrm{a}}$} \\
\hline Males & 87 & $25(29)$ & & 84 & $24(29)$ & & 85 & $20(24)$ & \\
\hline \multicolumn{10}{|l|}{ People arriving from: } \\
\hline European countries & 91 & $23(25)$ & \multirow{2}{*}{$0.9^{\mathrm{a}}$} & 87 & $29(33)$ & \multirow{2}{*}{0.2} & 88 & $22(25)$ & \multirow{2}{*}{$0.5^{\mathrm{a}}$} \\
\hline Non-European countries & 20 & $4(20)$ & & 20 & $3(15)$ & & 20 & $3(15)$ & \\
\hline $\begin{array}{l}\text { Countries competing in } \\
\text { EURO } 2012\end{array}$ & 78 & $21(27)$ & \multirow{2}{*}{0.3} & 74 & $26(35)$ & \multirow{2}{*}{0.08} & 75 & $20(27)$ & \multirow{2}{*}{$0.3^{\mathrm{a}}$} \\
\hline Other countries & 33 & $6(18)$ & & 33 & $6(18)$ & & 33 & $5(15)$ & \\
\hline $\begin{array}{l}\text { Countries with measles } \\
\text { rate }>1 \text { per } 100,000\end{array}$ & $\mathrm{n} / \mathrm{a}$ & $\mathrm{n} / \mathrm{a}$ & $\mathrm{n} / \mathrm{a}$ & $\mathrm{n} / \mathrm{a}$ & $\mathrm{n} / \mathrm{a}$ & $\mathrm{n} / \mathrm{a}$ & 48 & $15(31)$ & \multirow{2}{*}{0.07} \\
\hline Other countries & $\mathrm{n} / \mathrm{a}$ & $\mathrm{n} / \mathrm{a}$ & $\mathrm{n} / \mathrm{a}$ & $\mathrm{n} / \mathrm{a}$ & $\mathrm{n} / \mathrm{a}$ & $\mathrm{n} / \mathrm{a}$ & 60 & $10(17)$ & \\
\hline \multicolumn{10}{|l|}{ People who: } \\
\hline Visited EURO 2012 & 111 & $27(24)$ & \multirow[b]{2}{*}{$<0.0001^{\mathrm{a}}$} & 107 & $32(30)$ & \multirow[b]{2}{*}{$<0.001$} & 108 & $25(23)$ & \multirow[b]{2}{*}{0.03} \\
\hline $\begin{array}{l}\text { People who did not visit } \\
\text { EURO } 2012\end{array}$ & 193 & $4(2)$ & & 178 & $21(12)$ & & 176 & $27(15)$ & \\
\hline
\end{tabular}




\section{FIGURE 1}

Information sources accessed by fans who actively looked for travel health advice, European football tournament 2012

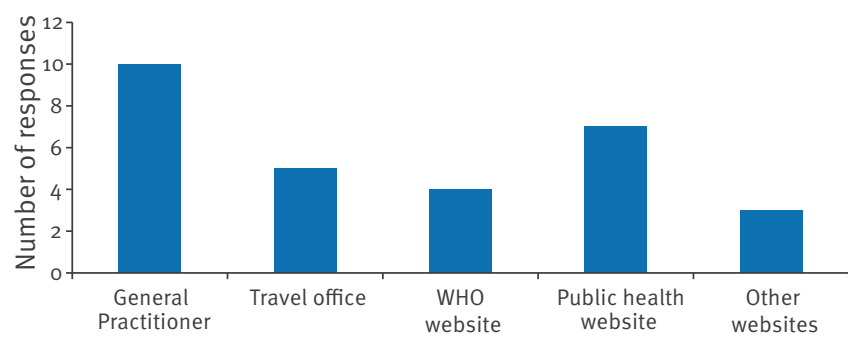

WHO: World Health Organization.

\section{FIGURE 2}

Information sources for fans who passively received travel health advice, European football tournament 2012

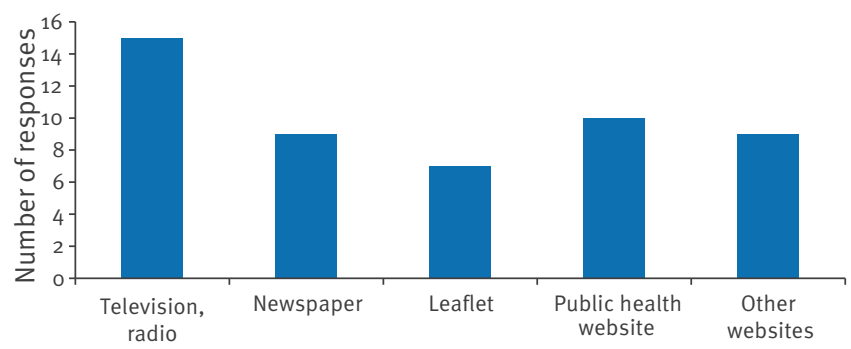

surveys enabling easy and rapid access to target populations at relatively low costs (the first post was "liked" by 325 people and the second post by 684 ). In epidemiology studies, social media should not be disregarded as basic tools to engage the public as demonstrated by other studies [8]. However, usage of social networks for public health purposes is still in its infancy [9]. In our study the majority of respondents were young, Englishspeaking users of the UEFA Facebook page. We believe that the response rate could have been higher if the survey had been posted not after but also during the tournament, which was not feasible at that time due to organisational procedures. Furthermore responses received in online questionnaires cannot be validated, unless cross-checking questions are included, which increase the length of the survey and thereby may make it less attractive specifically to respondents recruited via social media. Studies are needed to evaluate the type of groups that are likely to respond and whether they are representative of the population of interest.

Our survey could be adopted for rapid evaluation of the effectiveness of public health campaigns, for example during upcoming mass gathering such as the Olympics. The effectiveness of communication strategies should be constantly validated and adjusted as required.
Acknowledgments

We would like to thank WHO and ECDC for their comments to our initial questionnaire and assistance in disseminating the survey through their social networking channels. We would like to also thank EPIET coordinator Dr. Pawel Stefanoff for his helpful comments.

\section{References}

1. Ronveaux O, Quoilin S, Van Loock F. Infectious disease surveillance in Belgium during the Euro 2000 football tournament. Euro Surveill. 2000;4(25):pii=1576. Available from: http://www.eurosurveillance.org/ViewArticle. aspx?Articleld $=1576$

2. Coulombier D. Surveillance for the World Cup, France, 1998. Euro Surveill. 1998;2(24):pii=1204. Available from: http:// www.eurosurveillance.org/ViewArticle.aspx?Articleld=1204

3. European Centre of Disease Prevention and Control (ECDC). Surveillance Report: ECDC measles and rubella monitoring (EMMO). Issue 12; June 2012. Stockholm: ECDC. [Accessed June 2011]. Available from: http://ecdc.europa.eu/en/publications/ Publications/2012June13_SUR_measles_rubella_report.pdf

4. Health advice for Travellers to Poland and Ukraine for the 2012 UEFA European Football Championship. Geneva: World Health Organization; 2012. [Accessed May 2011]. Available from: http://www.euro. who.int/_data/assets/pdf_file/0004/158998/ Health_Travel_Advice_2012_UEFA_v7.pdf

5. Survey on travel health advice among visitors to Poland and Ukraine during EURO 2012. Warsaw: National Institute of Public Health. Available from: https://www.surveymonkey.com/s/ GRSTBW7

6. Howland JF, Conover C. Social Network as Outbreak Investigation Tool. Emerg Infect Dis. 2011;17(9)1765-6.

7. Schein R, Wilson K, Keelan J. Literature review on effectiveness of the use of social media. A report for Peel public health. 2010. [Accessed July 2012]. Retrieved from: http://www. peelregion.ca/health/resources/pdf/socialmedia.pdf 